\title{
MICROALGAE OF PROTECTED LAKES OF NORTHWESTERN UKRAINE
}

\author{
Yuriy Malakhov ${ }^{1}$, Olha Kryvosheia \& Petro Tsarenko
}

\begin{abstract}
The paper reports the first comprehensive study of microalgal species composition in four lakes of Volhynian Polissya (northwestern Ukraine), in which 271 species (279 intraspecific taxa) of 11 microalgal phyla were identified. Four dominant phytoplankton assemblages were determined for each lake. Bacillariophyta and Charophyta formed more than half (59.2\%) of the taxonomic list, accounting for 94 and 66 species respectively. Desmidiaceae was the most diverse family, with 44 species (47 intraspecific taxa) of microalgae. The four lakes are highly dissimilar in species richness and composition, having only 8 (2.9\%) species in common. Lake Cheremske had the highest number of algal species - 137 (144). Lake Bile, Lake Somyne and Lake Redychi were much less diverse, with 105, 79 (80) and 75 (78) species respectively. Morphological descriptions, original micrographies and figures are presented for a number of species, including some not previously documented in Ukraine: Chromulina cf. verrucosa G. A. Klebs, Eunotia myrmica Lange-Bert. and E. tetraodon Ehrenb. The lakes, which are almost pristine or are recovering, maintain diverse and valuable algal floras, making them important sites in the Pan-European ecological network.
\end{abstract}

Key words: microalgae, diversity, distribution, phytoplankton, lakes, nature reserves, Volhynian Polissya

Yuriy Malakhov, Olga Kryvosheia \& Petro Tsarenko, Department of Phycology, M. G. Kholodny Institute of Botany, National Academy of Sciences of Ukraine,2 TereshchenkivskaSt.,01601,Kyiv,Ukraine; e-mails:yur.malakhov@gmail.com,olja_km@mail.ru,ptsar@ukr.net

\section{INTRODUCTION}

Phycological and limnological studies in the Polesie region, and particularly in northwestern Polesie, have been carried out for almost a century (e.g., Wolsky 1927; Ernest 1939; Masjuk 1958; Asaul 1962; Tsarenko 1984, 2014a, b; Kovalenko 1997; Kryvenda 2007; Bukhtiyarova 2008; Palamar-Mordvintseva et al. 2009). In these studies, most of the researchers' attention was focused on the algal flora and species composition of various lakes in the Svityaz algofloristic area (PalamarMordvintseva \& Tsarenko 2015). This lake and wetland assemblage is in the Western Bug River Basin and is part of the West Polesie Trilateral Transboundary Biosphere Reserve (Chmelevski et al. 2015). With more than 950 recorded species, this reserve is considered to be a hotspot of the country's algal biodiversity (Tsarenko 2014a). The nearby Polish lakes also show high levels of algal

\footnotetext{
1 Corresponding author
}

diversity, with 341 recorded species of green conjugates alone (Pasztaleniec \& Poniewozik 2010; Chmelevski et al. 2015). Even with such extensive study, there is room for much more investigation of algal biodiversity in Ukraine and its neighboring countries.

Polesia and its subregion Volhynian Polissya (northwestern Ukraine) form one of several major core areas of the Pan-European Ecological Network for Central and Eastern Europe. Together these core areas maintain ecological coherence and provide important wildlife corridors (Jongman et al. 2011). In Ukraine's national econetwork, Volhynian Polissya is part of the Polissian nature corridor, which consists of 16 cores covering more than 847,000 ha (Fig. 1). Each core is in a nature reserve or national park, the highest national conservation categories for protected land (Anonymous 2012). Half of these cores are located just within Volhynian Polissya (Fig. 1: 1-6, 11, 12). Together with the adjacent Pojezierze 


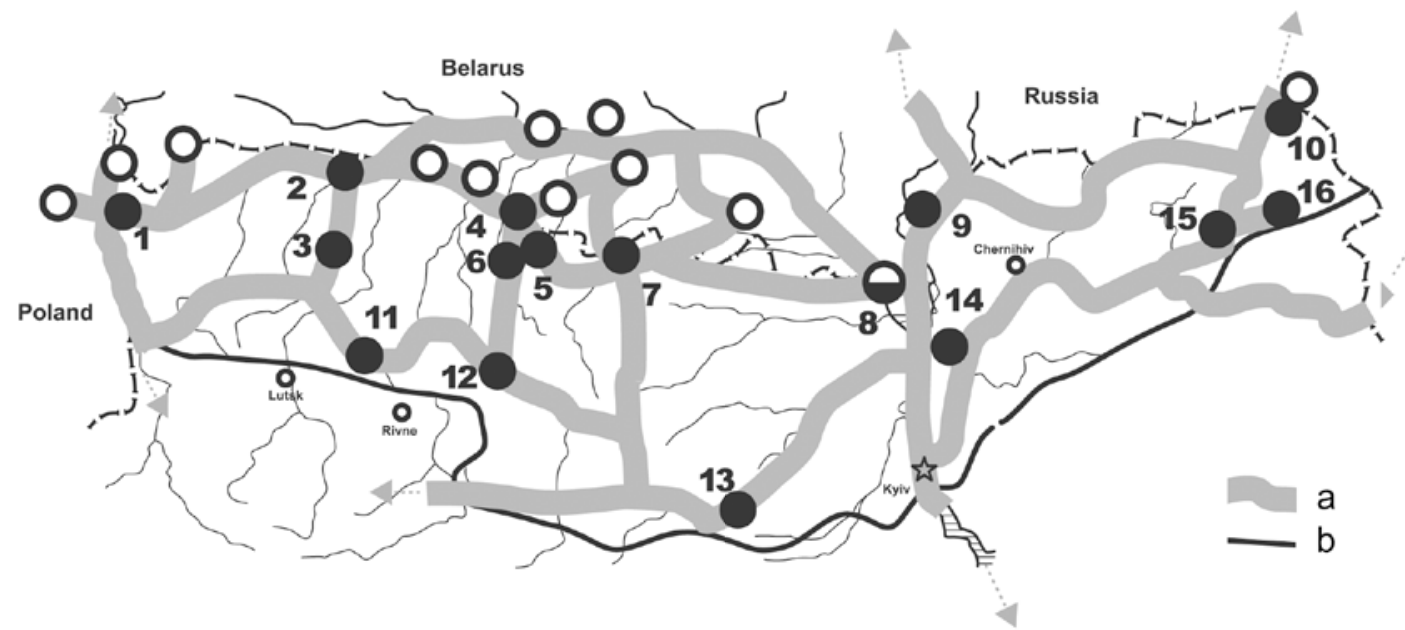

Fig. 1. Scheme of Ukrainian Polissya econetwork (adapted from Anonymous 2012). Major cores of the network: 1 - Shatsk, 2 - Prypyat-Stokhid, 3 - Biloozersko-Cheremske, 4 - Perebrody, 5 - Syra Pohonia, 6 - Somyne, 7 - Ubortsko-Bolotnytske, 8 - Chornobyl, 9 - Dniprovske, 10 - Desnyansko-Starohutske, 11 - Tsuman, 12 - Nadslychanske, 13 - Korostyshiv, 14 Mizhrichenske, 15 - Mezynsko-Shostkynske, 16 - Verkhnyoesmanske; a - major nature corridors, b - southern border of Polesia region, $\bullet-$ major econetwork cores in Ukraine, $\mathbf{0}$ - indicate cores of Polesia econetwork in Poland, Belarus and Russia.

Łęczyńsko-Włodawskie lake district in Poland, the Biloozersko-Cheremske, Perebrody, PrypyatStokhid, Shatsk, Somnye and Syra Pohonia cores are recognized as important Ramsar sites (Marushevsky \& Zharuk 2006; Chmelevski et al. 2015; https://rsis.ramsar.org).

In this study we aimed to fill a gap in knowledge of the algal flora of lakes other than those of Shatsk National Park. Despite the high status and value of these lakes, the microalgal data for them are scarce or even absent. We assessed microalgae species diversity and its conservation value in the protected lakes of the Rivnensky and Cheremsky Nature Reserves, which constitute the BiloozerskoCheremske and Somyne cores of the Ukrainian Polissya econetwork.

\section{MATERIALS AND METHODS}

This study is based on 53 algal samples collected during repeated field trips to the Rivnensky and Cheremsky Nature Reserves in July of 2003-2008 and 2013-2014. Our sampling covered the main aquatic complexes of the reserves: Lake Bile, Lake Somyne, Lake Redychi and Lake Cheremske (Fig. 2). Plankton and benthos samples were taken with a plankton net $(64 \mu \mathrm{m}$ mesh) and a siphon. Periphytic samples were collected together with fragments of aquatic plants or macroalgal filaments. Most of the samples were fixed in $4 \%$ solution of formaldehyde, and some were maintained live. We measured water $\mathrm{pH}$ immediately after sample collection with an SX 620 portable $\mathrm{pH}$-meter.

Further analyses in the laboratory employed light and scanning electron microscopy. For the study we also established enrichment cultures with and without

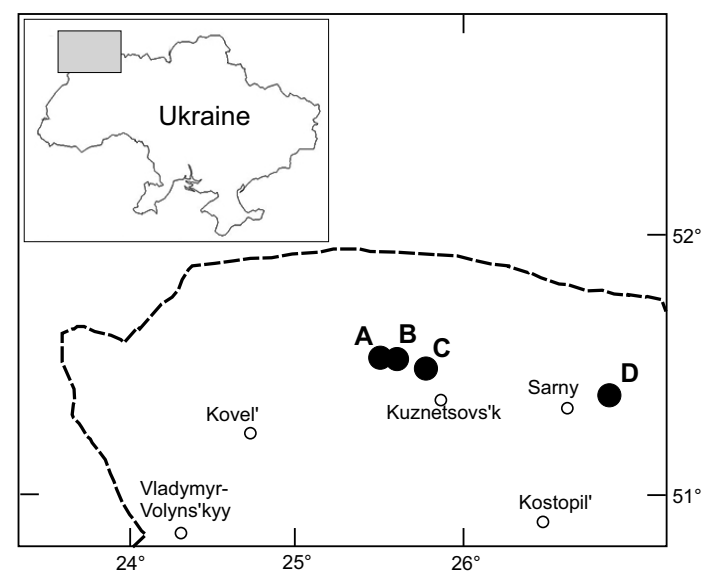

Fig. 2. Sampling locations on map of Ukraine. A - Lake Cheremske, B - Lake Redychi, C - Lake Bile, D - Lake Somyne. 
addition of BBM medium (Andersen 2005). Unialgal culturing was continued on sterile solid (1.5\% agar) BBM medium in growth chambers (L:D 12:12, 3000$4000 \mathrm{~lm}$ flux).

Algal colonies on agar plates were examined with an MBS-10 stereomicroscope; separate specimens of microalgae were examined and identified using ZEISS Primo Star (objectives: Plan Achromat 10×, 40×, immersion-oil 100×) and MBI-6 phase-contrast (Plan Achromat 40×, immersion-oil 90×) light microscopes. For identification of diatoms, frustules were cleaned in hot hydrogen peroxide (Prygiel \& Coste 2000) and mounted in Naphrax synthetic resin. Cleaned diatom frustules were also examined using a JEM-1230 scanning electron microscope at the M. G. Kholodny Institute of Botany, National Academy of Sciences of Ukraine.

The taxonomic list (see Appendix) follows the system presented in the Algae of Ukraine series (Tsarenko et al. 2006, 2009, 2011, 2014). Taxonomy of the phylum Cyanoprokaryota follows Komárek and Anagnostidis (1998, 2005) and Komárek (2013).

The dendrogram was built in PAST 3.11 (Hammer et al. 2001).

\section{CHARACTERISTICS OF SAMPLING SITES}

\section{AND STUDY REGION}

Mixed broadleaf and coniferous forest is the most common vegetation type in Volhynian Polissya. Other characteristic features of this region include humid continental climate, the prevalence of lowland relief, and a dense hydrographic network. Another attribute of the region is its many lakes, whose presence is related to the occurrence of karst formations and post-glacial activity (Marynych \& Shyshchenko 2005). The majority of Volhynian Polissya lakes show hydrocarbonate and calcium mineralization, with neutral or slightly acidic water $(\mathrm{pH}=6.5-7.0)$. Hydrochemical parameters of the studied lakes are given in Table 1.

Lake Somyne is located in the Rivnensky Nature Reserve (RNR), Rivne oblast (province), Sarny raion (district). The center of the lake is at $51^{\circ} 23^{\prime} 07^{\prime \prime} \mathrm{N}$, $26^{\circ} 51^{\prime} 04^{\prime \prime} \mathrm{E}$. Its surface area is 61 ha and its maximum depth is $13 \mathrm{~m}$. Lake Somyne is of karst origin (Marushevsky \& Zharuk 2006). Its emerged shoreline vegetation is weakly developed. An earthen dike limits the lake's catchment from the western side. The lake is surrounded by mesotrophic swamps on the other three sides. To the north, adjacent wetlands drain directly into the lake, sometimes forming floating vegetation mats on the lake surface. During sampling the lake water was yellowish brown and its turbidity obscured the lake bottom.

Lake Bile is also located in the RNR, Rivne oblast, Volodymyrets raion. The lake center is at $51^{\circ} 29^{\prime} 01^{\prime \prime} \mathrm{N}$, $26^{\circ} 45^{\prime} 13^{\prime \prime} \mathrm{E}$. Its surface area is 453 ha and its maximum depth is $26 \mathrm{~m}$. This lake is also of karst origin (Marushevsky \& Zharuk 2006). It has a large, shallow (2-2.5 m deep) littoral in the north and northeastern parts of the lake, which continues up to $200 \mathrm{~m}$ from the shoreline. After that the littoral breaks, with a sudden increase in depth. The shoreline vegetation is sparse. The high transparency of the water allows plant growth at considerable depths (Orlov et al. 2009).

Lake Cheremske and Lake Redychi are both located in the Cheremsky Nature Reserve (ChNR), Volyn oblast, Manevychi raion. The center of Lake Cheremske is at $51^{\circ} 31^{\prime} 27^{\prime \prime} \mathrm{N}, 25^{\circ} 32^{\prime} 12^{\prime \prime} \mathrm{E}$. Its surface area is 7.7 ha and its maximum depth is $7 \mathrm{~m}$. The center of Lake Redychi is at $51^{\circ} 31^{\prime} 30^{\prime \prime} \mathrm{N}, 25^{\circ} 35^{\prime} 07^{\prime \prime}$. Its surface area is 14 ha and its maximum depth is $4.5 \mathrm{~m}$. These drainage lakes are of both glacial and karst origin. They were formed in the course of the transformation of a large drainage lake (covering more than 1000 ha) into what is now Cheremske bog. Both lakes are low in plant species richness but a number of nationally rare plants are found there (Konishchuk 2005).

\section{RESULTS AND DISCUSSION}

During our investigation of the lakes we found 271 species, (279 intraspecific taxa) belonging to 137 genera, 74 families, 40 orders, 15 classes and 11 phyla of microalgae (Table 2).

Table 1. Hydrochemical characteristics of the studied lakes.

\begin{tabular}{c|c|c|c|c|c|c|c|c}
\hline Lake & $\begin{array}{c}\text { Conductivity } \\
\mu \mathrm{S} / \mathrm{cm}^{-1}\end{array}$ & $\mathrm{pH}$ & $\begin{array}{c}\text { Dissolved } \\
\mathrm{O}_{2} \mathrm{mg} / \mathrm{l}^{-1}\end{array}$ & $\begin{array}{c}\mathrm{NH}_{4}^{+} \\
\mathrm{mg} / \mathrm{l}^{-1}\end{array}$ & $\begin{array}{c}\mathrm{NO}_{2}^{-} \\
\mathrm{mg} / \mathrm{l}^{-1}\end{array}$ & $\begin{array}{c}\mathrm{NO}_{3}^{-} \\
\mathrm{mg} / \mathrm{l}^{-1}\end{array}$ & $\begin{array}{c}\mathrm{PO}_{4}^{3-} \\
\mathrm{mg} / \mathrm{l}^{-1}\end{array}$ & $\begin{array}{c}\mathrm{Fe}^{3+} \\
\mathrm{mg} / \mathrm{l}^{-1}\end{array}$ \\
\hline Redychi & 63 & 6.46 & 9.5 & 0.20 & $<0.01$ & $<0.01$ & - & 1.1 \\
\hline Cheremske & 70 & $6.16-6.50$ & 9.7 & 0.22 & $<0.01$ & $<0.01$ & - & 1.2 \\
\hline Somyne & $(76)-102-160$ & $(5.50)-6.67-(7.10)$ & - & $0.64-(2.2)$ & $<0.01$ & $0.01-2.01$ & 0.049 & $(0.5)-1.0-3.0$ \\
\hline Bile & 95 & $7.34-(8.50)$ & 9.6 & 0.45 & $<0.03$ & 2.01 & - & 1.5 \\
\hline
\end{tabular}


Bacillariophyta (94 species) and Charophyta (66 species) form the basis of the algal species composition of all of the studied waterbodies, accounting for more than half $(59.2 \%)$ of the taxonomic list. Chlorophyta and Cyanoprokaryota contribute less to the diversity of the lakes: $53(19.6 \%)$ and $28(10.3 \%)$ species respectively.

Among the principal families, Desmidiaceae showed the most diversity, adding 44 species (47 intraspecific taxa) to the taxonomic list.

Other noteworthy families are Pinnulariaceae (15 species, 18 intraspecific taxa), Cymbellaceae (10 species), Gomphonemataceae (10 species), Eunotiaceae ( 9 species) and Fragilariaceae (7 species) - Bacillariophyta; Selenastraceae (12 species) and Scenedesmaceae (9 species) - Chlorophyta; Closteriaceae (13 species, 14 intraspecific taxa) - Charophyta; and Euglenaceae (10 species, 11 intraspecific taxa) - Euglenophyta. The basis of algal diversity of the investigated lakes consists of desmids, pennate diatoms, and coccoid green and euglenoid algae. Lake Cheremske yielded the highest number of algal species (137 species, 144 intraspecific taxa). The species diversity of Lake Bile appeared to be lower (105 species). Lake Somyne (79 species, 80 intraspecific taxa) and Lake Redychi (75 species, 78 intraspecific taxa) showed low algal species richness.

Jaccard similarity coefficient calculations showed the four lakes to be floristically distinct rather than similar (Fig. 3). Lake Cheremske and Lake Redychi showed the highest similarity (0.37); Lake Cheremske and Lake Bile were the most distant pair (0.11). Lake Bile and Lake Somyne were also distant (0.19). Such low Jaccard coefficients indicate specific species compositions and heterogeneity of habitat conditions. The four waterbodies had only 8 species $(2.9 \%)$ in common: Stephanodiscus hantzschii Grunow, Cyclotella meneghiniana Kütz., Gomphonema acuminatum Ehrenb., Cocconeis placentula Ehrenb., Brachysira vitrea (Grunow) R. Ross, Navicula radiosa Kütz., Oedogonium sp. ster. and Aphanochaete repens A. Braun.

During microscopic examination, the majority of microalgae species occurred sporadically, with a few being dominant or fairly abundant. Basing on these observations, we identified dominant species assemblages in the phytoplankton of the researched lakes.

For Lake Bile, pelagic samples showed that the chroococcoid cyanoprokaryotes were fairly diverse, with Aphanocapsa planctonica (G. M. Sm.) Komárek \& Anagn., Coelosphaerium kuetzingianum Nägeli, Snowella lacustris (Chodat) Komárek \& Hindák and Woronichinia naegeliana (Unger) Elenkin present. The occasional findings of Aphanothece endophytica (West \& G. S. West) Komárk.-Legn. \& Cronberg in colonial mucilage of Woronichinia naegeliana were especially

Table 2. Taxonomic spectrum of algal flora of the studied lakes.

\begin{tabular}{|c|c|c|c|c|c|c|}
\hline \multirow{2}{*}{ Phylum } & \multicolumn{5}{|c|}{ Quantity } & \multirow{2}{*}{$\begin{array}{c}\% \text { of total } \\
\text { species number }\end{array}$} \\
\hline & classes & orders & families & genera & species (int. taxa) & \\
\hline Cyanoprokaryota & 1 & 3 & 9 & 23 & $28(28)$ & $10.33 \%$ \\
\hline Euglenophyta & 1 & 1 & 2 & 5 & $11(12)$ & $4.06 \%$ \\
\hline Chrysophyta & 1 & 3 & 5 & 7 & $8(8)$ & $2.95 \%$ \\
\hline Xanthophyta & 1 & 2 & 3 & 2 & $4(4)$ & $1.85 \%$ \\
\hline Eustigmatophyta & 1 & 1 & 1 & 1 & $1(1)$ & $0.37 \%$ \\
\hline Bacillariophyta & 3 & 13 & 24 & 40 & $94(97)$ & $34.69 \%$ \\
\hline Dinophyta & 1 & 2 & 2 & 2 & $2(2)$ & $0.74 \%$ \\
\hline Cryptophyta & 1 & 1 & 1 & 1 & $2(2)$ & $0.74 \%$ \\
\hline Glaucocystophyta & 1 & 1 & 1 & 1 & $1(1)$ & $0.37 \%$ \\
\hline Chlorophyta & 2 & 9 & 20 & 37 & $54(54)$ & $19.56 \%$ \\
\hline Charophyta & 2 & 4 & 6 & 18 & $66(70)$ & $24.35 \%$ \\
\hline Total & 15 & 40 & 74 & 137 & $271(279)$ & $100.00 \%$ \\
\hline
\end{tabular}




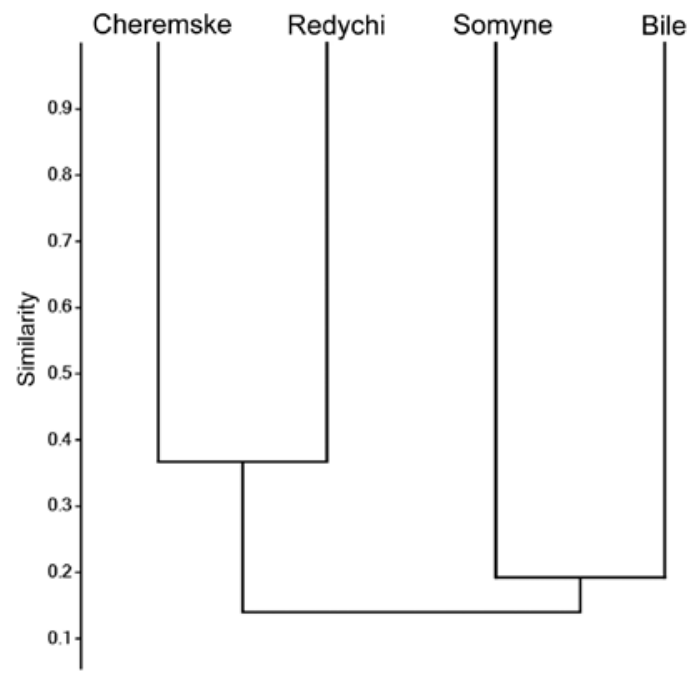

Fig. 3. Jaccard similarity dendrogram, built by single-linkage clustering.

interesting, as its presence indicates clear water (Komárek \& Anagnostidis 1998; Kovalenko 2009). Second most frequent in the Lake Bile phytoplankton was the group of diatom species Tabellaria flocculosa (Roth) Kütz., Fragillaria crotonensis Kitton, Eunotia pectinalis (Kütz.) Rabenhorst and Navicula radiosa. Among the less frequent but still typical findings were the unicellular thecate dinoflagellate Ceratium hirundinella (C. Agardh) Kütz. and the chrysophycean colonial Dinobryon divergens O. E. Imhof. The shallow littoral of the lake showed different species composition patterns and overall greater microalgal abundance than the lake's pelagial. In the shallows, the cyanoprokaryotic diatom community was complemented by desmid and coccoid green specimens. We suggest that the increased development of microalgae in the shallow near-shore zone can be explained by the elevated concentrations of biogenic nutrients that flow from the lakeshore and become trapped there.

Pelagic samples from Lake Somyne were conspicuously poor, both qualitatively and quantitatively. The most frequent findings were the dinoflagellates Ceratium hirundinella and Peridinium gatunense Nygaard (Fig. 4). These species can be considered the absolute dominants of the lake's phytoplankton. Massive development of $P$. gatunense was previously observed in lakes of Ukrainian Polissya (Kapustin 2013). This species is known to cause massive blooms, particularly in lentic ecosystems of oligotrophic and mesotrophic lakes such as Lake Kinneret in Israel (Hickel \& Pollingher 1988; Krakhmalnyi et al. 2014). According to Oda and Bicudo (2006), peak development of $P$. gatunense occurs during periods of evident limnological stress such as nutrient depletion, allowing this species to take advantage of reduced competition. Our observation of high abundance of $P$. gatunense in July samples suggests that Lake Somyne may experience stress during warm summer months, but further study of the lake's hydrology is needed to verify this.

In addition to dinoflagellates, we frequently observed scattered specimens of cyanoprokaryotes (Aphanocapsa planctonica), diatoms [Acanthoceras zachariasii (Brun) Simonsen, Tabellaria flocculosa, Navicula radiosa, Brachysira vitrea], chrysophytes (Pseudokephiryon poculum W. Conrad) and green algae [Monoraphidium arcuatum (Korschikov) Hindák, M. contortum (Thur.) Komárk.-Legn., Kirchneriella obesa (West) Schmidle]. We also found the epizoic euglenid Colacium cyclopicola (Gickl.) Woron. \& T. G. Popova (Fig. 5) in the microscopic crustacean plankton relatively frequently. Palustrine parts of the lake were marked by the presence of Euglena gracilis G. A. Klebs, Trachelomonas volvocina Ehrenb., T. volvocina var. punctata Playfair, Phacus spp. (Euglenophyta); Ophiocytium spp. (Xanthophyta); Cocconeis spp., Pinnularia spp. and Ulnaria spp. (Bacillariophyta).

The low algal diversity of the material from Lake Somyne may be explained in part by weak water mineralization. The elevated content of humic substances originating from the adjacent swamps may be another factor limiting algal growth in the lake. The yellowish brown coloration of the lake water indicates high content of humic compounds, which typically causes water acidification, although the average $\mathrm{pH} 7.1$ recorded at the time of sampling does not mark Lake Somyne as acidic.

The pelagic phytoplankton communities of Lake Cheremske and Lake Redychi can also be 

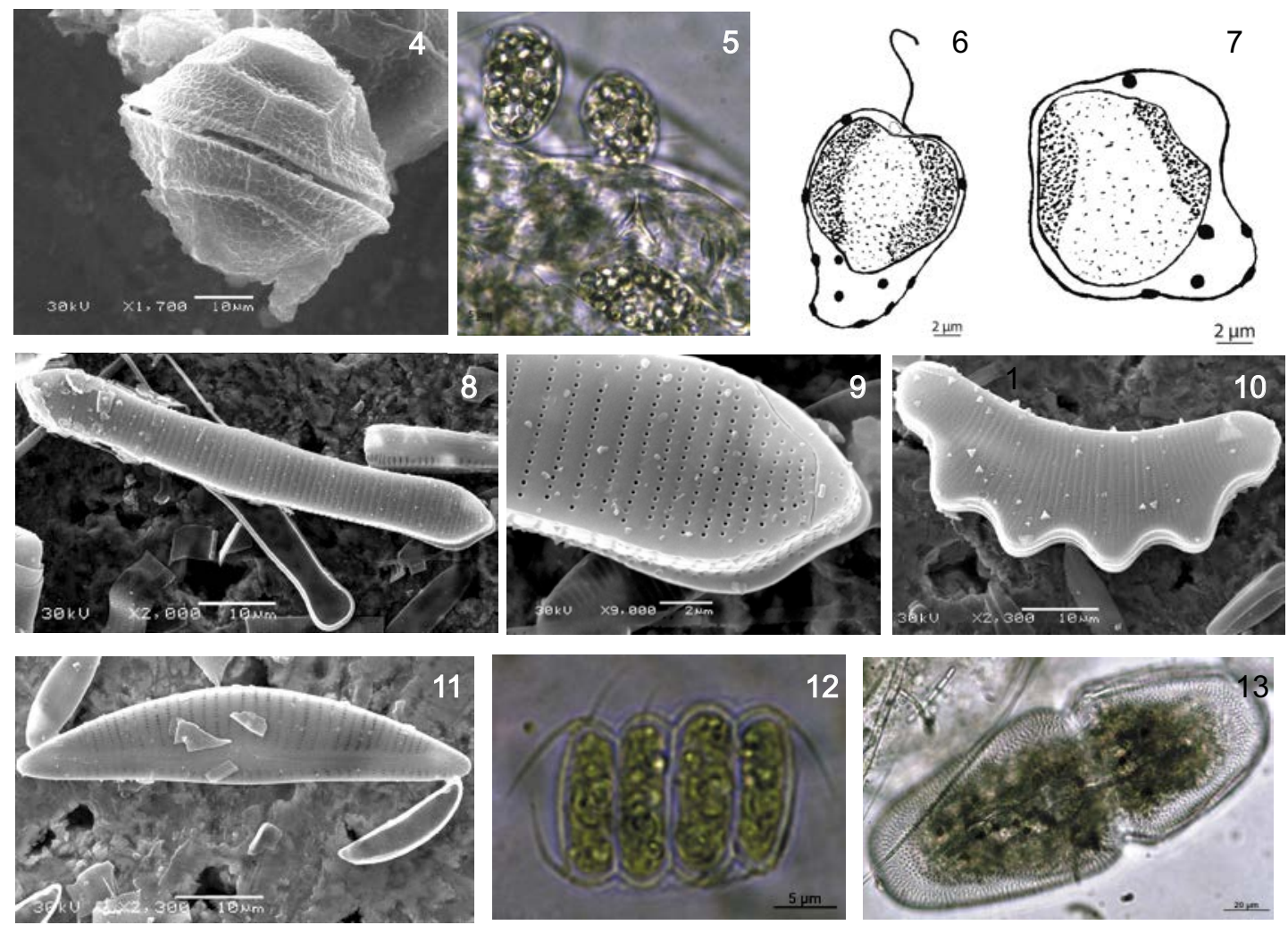

Figs 4-13. 4 - Peridinium gatunense Nygaard from Lake Somyne; 5 - Colacium cyclopicola (Gick1.) Woron. \& T. G. Popova from Lake Bile; 6 \& 7 - monad form (6) and amoeboid form (7) of Chromulina cf. verrucosa G. A. Klebs from Lake Somyne; 8 \& 9 - Eunotia myrmica Lange-Bert. from Lake Redychi; 10 - E. tetraodon Ehrenb. from Lake Redychi; 11 - Encyonema vulgare Krammer from Lake Somyne; 12 - Desmodesmus magnus (Meyen) P. Tsarenko from Lake Bile; 13 - Actinotaenium turgidum (Bréb. ex Ralfs) Teiling ex Růžička \& Pouzar from Lake Bile.

characterized as low in species abundance and diversity. Despite their proximity and similar morphology, they differ in dominant species complexes. Lake Cheremske is dominated by Trachelomonas volvocina, Tabellaria flocculosa and Gomphonema acuminatum, while Lake Redchyi is dominated by Tabellaria fenestrata (Lyngb.) Kütz., T. flocculosa and Cocconeis placentula. This difference may be due to differences in the ecological amplitudes of particular species, or to hydroecological conditions such as flow level, temperature regime, or the presence or absence of groundwater discharge. As in Lake Somyne, the palustrine parts of both lakes showed higher shares of particular algal phyla (Chlorophyta, Xanthophyta, Charophyta, Bacillariophyta) in the dominant species assemblages.
The most distinctive algal complex was recorded in samples from the periphyton of vascular plant associations: Gomphonema acuminatum, Eunotia bilunaris (Ehrenb.) Mills., E. pectinalis, Navicula radiosa, Pinnularia subcapitata W. Greg., Tabellaria flocculosa, Mougeotia sp. ster., Oedogonium sp.ster., Palmodictyon viride Kütz., Ophiocytium capitatum Wolle, Quadrigula korschikovii Komárek, Cylindrocystis brebissonii (Menegh. ex Ralfs) De Bary, Closterium acutum Bréb., C. juncidum Ralfs, Staurastrum boreale West \& G. S. West and Xanthidium cristatum Bréb ex Ralfs. This peculiar species composition is characteristic of the adjacent swamps. Its presence in the lakes demonstrates the strong influence of the swamp on the lakes' water. 
We also recorded 69 microalgal taxa that are new ${ }^{*}$ ) or rare $\left(^{* *}\right)$ for the Ukrainian algal flora. Morphological descriptions, original photomicrographs and figures for some of them are presented below.

\section{CHRYSOPHYTA}

\section{Chromulinaceae Engler}

${ }^{*}$ Chromulina cf. verrucosa $\mathrm{G}$. A. Klebs

Collecting SITE: Lake Somyne.

Figs $6 \& 7$

Cells oval, truncated at anterior, slightly excavated at attachment of flagella. Cells metabolic, especially at posterior end. Cell shape rounded to oval or oblong, with appendage at posterior end. Observed cells may also persist in amoeboid state for a relatively long time. Periplast covered with large, irregular verrucae. One flagellum nearly equal to cell length visible by LM. Cells contain single, large, trough-shaped, yellowish brown chloroplast. One small contractile vacuole located at anterior end of cell near base of flagellum. Cell length $16.5 \mu \mathrm{m}$, width $12 \mu \mathrm{m}$.

Specimens of $C h$. cf. verrucosa were found in enrichment cultures from Lake Somyne. This species is also known from Central Europe (Germany) and European Russia (Guiry \& Guiry 2016; Matvienko 1965). Freshwater species, planktic in lentic waters.

\section{BACILLARIOPHYTA}

Eunotiaceae Kütz.

${ }^{*}$ Eunotia myrmica Lange-Bert. Figs $8 \& 9$

Eunotia formica sensu Hustedt, E. formica sensu Mölder \& Tynni

\section{COLleCting SITE: Lake Redychi.}

Valves slightly bent to almost linear. Central part of valve slightly inflated on dorsal and ventral sides. Ends of valve weakly capitate with cuneate to acuminated punctate apices. Terminal parts of raphe bent towards dorsal margin. Length of valves 63.4$101.3 \mu \mathrm{m}$, width $8.4-7.5 \mu \mathrm{m}$. Striae density 10 in $10 \mu \mathrm{m}$ in central part of valve, 13-14 in $10 \mu \mathrm{m}$ at apices. Areolae density 26 in $10 \mu \mathrm{m}$. Freshwater species.
The cognate taxon E. formica Ehrenb. was previously known from Ukrainian Polissya (Radzymovsky \& Polischuk 1970; Moshkova \& Vodopian 1975) and lakes of the Ukrainian Carpathians (Konenko et al. 1965; Tsarenko et al. 2009). Taking into account the revision of the E. formica complex (Lange-Bertalot et al. 2011), however, we recognize E. myrmica as a newly registered species in Ukraine. It is also known from Arctic Russia, Scandinavia, Canada and northern USA (Lange-Bertalot et al. 2011).

${ }^{*}$ Eunotia tetraodon Ehrenb. Fig. 10

Eunotia serra var. diadema (Ehrenb.) Patrick, E. serra var. tetraodon (Ehrenb.) Norpel

Collecting Site: Lake Redychi.

Valves highly convex, with four regular undulations on dorsal side. Apices wider than undulations, bluntly rounded. Terminal parts of raphe shifted closer to apices, bent towards dorsal margin. Length of valves 49.5-50.1 $\mu \mathrm{m}$, width 13.6-16.9 $\mu \mathrm{m}$. Striae radial, of two types: complete (passing through whole breadth of valve) and short (present only on dorsal margin, more numerous on undulations, filling gaps between full-length striae). Striae density 10 in $10 \mu \mathrm{m}$ in central part of valve, 14-16 in $10 \mu \mathrm{m}$ at apices. Areolae density $22-23$ in $10 \mu \mathrm{m}$. Freshwater benthic species, acidophilic, xeno-oligosaprobic.

The cognate species Eunotia serra was previously reported from Ukrainian Polissya (Topachevsky \& Oksiyuk 1960) and the steppe zone (Vladimirova \& Litvinova 1964; Tsarenko et al. 2009). In light of the recent genus revision and reconsideration of some intraspecific taxa as separate species (Lange-Bertalot et al. 2011), we regard our finding of E. tetraodon as the first report for Ukraine. This species has a Holarctic distribution, found mostly in boreal-alpine habitats of Eurasia and North America (Lange-Bertalot et al. 2011).

Cymbellaceae Grev.

***Encyonema vulgare Krammer Fig. 11

COLLECTING SITES: Lake Somyne, Lake Cheremske and Lake Redychi. 
Valves dorsoventral, semi-lanceolate, with arcuate dorsal margin. Ventral margin slightly convex in central area, sometimes becoming linear. Apices broadly rounded. Length of valves 51.2-45.4 $\mu \mathrm{m}$, width 11.1-12.3 $\mu \mathrm{m}$, length/width ratio 4.6. Raphe linear, positioned laterally. Axial field narrow, shifted to ventral side and parallel to dorsal margin. Central field absent or indistinctly delineated. Striae radial, converging at ends of ventral side, 10-11 in $10 \mu \mathrm{m}$. Areolae density 25 in $10 \mu \mathrm{m}$.

This alga usually is found in oligotrophic waterbodies with low electrolyte content. This is the second finding in Ukraine (Kryvosheia \& Kryvenda 2015) and the first for Ukrainian Polissya. Encyonema vulgare was also reported from Poland, northwestern and southeastern USA, Colombia and China (Guiry \& Guiry 2016).

\section{Chlorophyta}

Scenedesmaceae Oltm.

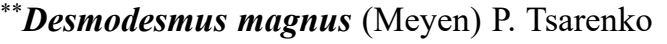
Fig. 12

Collecting SITES: Lake Bile and Lake Somyne.

Coenobia consists of four cylindrically oval cells with rounded poles and slightly convex external margin. Cell poles have linearly symmetric and bent spines. Cell length $14.5 \mu \mathrm{m}$, width $4.5 \mu \mathrm{m}$.

Occasional specimens of D. magnus were found in enrichment cultures from Lake Somyne and in samples from shallows of Lake Bile. It is a regionally rare protected species (Konishchuk et al. 2010). This freshwater alga occurs in the plankton and periphython of lakes and ponds. The species range is disjunctive and includes Eurasia, Africa, South America and Oceania (Guiry \& Guiry 2016).

\section{CHAROPHYTA}

Desmidiaceae Ralfs

\footnotetext{
** Actinotaenium turgidum (Bréb. ex Ralfs) Teiling ex Růžička \& Pouzar Fig. 13

Collecting Site: Lake Bile.

Cells large, ellipsoidal, slightly constricted.
}

Apices obtusely rounded to truncated. Finely porous, scrobiculate cell wall. Cell length $182 \mu \mathrm{m}$, width $76 \mu \mathrm{m}$.

Specimens of $A$. turgidum occurred very rarely (1-2 cells per slide) in samples from the shallow littoral of Lake Bile. This species is rare for the algal flora of Volhynian Polissya (PalamarMordvintseva et al. 2009). Benthic, planktic (tychoplanktic) in lakes, swamps and streams; mesosaprobic. The species range includes Europe, South Asia, South America, Australia and Oceania (Guiry \& Guiry 2016).

ACKNOwLEDGEMENTS. We are grateful to Dr. Vasyl Konishchuk for encouragement, fieldwork assistance in the Cheremsky Nature Reserve, and supplying data on the hydrochemical characteristics of the studied lakes; Galyna Lilitska (Phycology Department, M. G. Kholodny Institute of Botany, National Academy of Sciences of Ukraine) for help in identifying particular desmidian algae; the administration and staff of the Rivnensky and Cheremsky Nature Reserves for financial and organizational support; Ms. Eliza Oldach and Mrs Maria Malakhova for proofreading and editing an earlier version of the manuscript; and two anonymous reviewers for constructive remarks and suggestions.

\section{REFERENCES}

Andersen R. A. (ed.) 2005. Algal Culturing Techniques. Elsevier Academic Press, London.

ANONYMous 2012. Natsionalna dopovid' pro stan formuvannya ekomerezhi Ukrajiny za 2006-2010 roky. Ministry of Ecology and Natural Resources of Ukraine. Grin' D.S., Kherson.

AsAul Z. I. 1962. Euglenophyta of the West Ukrainian Polessye lakes. Ukrayins 'k. Bot. Zhurn. 19(1): 52-57 (in Ukrainian with English summary).

Bukhtiyarova L. N. 2008. Preliminary data on diatoms from Cheremsky Natural Reserve, Ukrainian Polissya. In: YE. Likhoshway (ed.), Proceedings of the Nineteenth International Diatom Symposium, p. 23. Biopress Ltd., Bristol.

Chmielewski T. J., Chmielewski S., Kulak A., MichaliKŚNIEŻEK M. \& MAŚLANKO W. 2015. Landscapes of the West Polesie regional identity and its transformation over last half century. Poleski Park Narodowy, Lublin - Urszulin.

ERNEST K. 1939. Une contribution à la connaisance des diatomées de la Polesie. Spraw. Komis. Fizjogr. 72: 493-498 (in Polish with French summary). 
Guiry M. D. \& Guiry G. M. 2016. AlgaeBase. World-wide electronic publication, National University of Ireland, Galway. http://www.algaebase.org.

Hammer Ø., Harper D. A. T. \& Ryan P. D. 2001. PAST: Paleontological statistics software package for education and data analysis. Palaeontologia Electronica 4(1): 1-9.

Hickel B. \& Pollingher U. 1988. Identification of the bloomforming Peridinium from Lake Kinneret (Israel) as $P$. gatunense (Dinophyceae). Brit. Phycol. J. 23(2): 115-119.

Jongman R. H. G., Bouwma I. M., Griffioen A., JonesWalters L., Van-Doorn A. M. 2011. The Pan European Ecological Network: PEEN. Landscape Ecol. 26: 311-326.

KAPUSTin D. A. 2013. Freshwater algae of the Polessian Nature Reserve (Ukraine). Algologia 23(1): 82-95 (in Russian with English summary).

KomáreK J. 2013. Cyanoprokaryota 3: Heterocytous Genera. In: B. BüDel, L. Krienitz, G. Gärtner \& M. SchagerL (eds), Süßwasserflora von Mitteleuropa 19(3): 1-1130. Springer Spektrum Berlin, Heidelberg.

KomáReK J. \& Anagnostidis K. 1998. Cyanoprokaryota 1. Teil: Chroococcales. In: H. ETTL, G. GäRTNER, H. HeYNIG \& D. Mollenhauer (eds), Süßwasserflora von Mitteleuropa 19(1): 1-548. Gustav Fischer, Jena - Stuttgart Lübeck - Ulm.

KomáReK J. \& Anagnostidis K. 2005. Cyanoprokaryota 2. Teil/ 2nd Part: Oscillatoriales. In: B. BüDEL, L. KRIENITZ, G. GärTnER \& M. SchaGERL (eds), Süßwasserflora von Mitteleuropa 19(2): 1-759. Elsevier Spektrum Akademischer Verlag, München.

Konenko G. D., Pidhaiko M. L. \& Radzymovsky D. O. 1965. Stavky lisostepovykh, stepovykh i girskykh regioniv Ukrainy. Hidrokhimichny ta hydrologichny narys. Naukova Dumka, Kyiv.

KonishchuK V. V. 2005. The classification of Cheremskiy Natural Reserve ecosystems with using a mapping method. Ukrainian Phytosociological Collection 23: 61-76 (in Ukrainian with English summary).

Konishchuk V. V., Andrienko T. L., Tsarenko P. M., BaIdashnikov O. O., Virchenko V. M., Vysotska O. P., Zelenko S. D., Kinder O. O., Konishchuk M. O., Kotenko A. G., Mateichyk V. I., Prydiuk M. P., Pryadko O. I., Tytar V. M. 2010. Red Data Book of Volyn Region. Naukoviy Visnik Volins'kogo Natzional'nogo Universitetu Imeni Lesi Ukrayinky. Seriya Biologichni Nauki 12: 157-176 (in Ukrainian with English summary).

Kovalenko O. V. 1997. New data on Cyanophyta of lakes of Shatsk Nature National Park (Ukrainian Polissya). Algologia 7(3): 289-296 (in Russian with English summary).

Krakhmalnyi A. F., Wasser S. P., Nevo E. \& Kapitanchuk L. M. 2014. New variety Peridinium gatunense Nygaard var. kinnereta Krachmalny (Dinophyta) from the Lake Kinneret (Israel). Algologia 24(2): 227-233 (in Russian with English summary).
Kryvenda A. A. 2007. Check-list of Lakes Diatoms Shazkyy National Natural Park. Chornomorskiy Botanichniy Zhurnal 3(1): 100-121 (in Ukrainian with English summary).

Kryvosheia O. M., Kryvenda A. A. 2015. New and rare species of Bacillariophyta from the basins of Regional Landscape Park "Nyzhnyovorsklyansky" (Ukraine). Algologia 25(3): 306-322 (in Russian with English summary).

Lange-Bertalot H., BąK M. \& Witkowski A. 2011. Diatoms of Europe: Diatoms of the European Inland Waters and Comparable Habitats. 6. Eunotia and some related genera. A.R.G. Gartner Verlag, Ruggel.

Marushevsky G. \& Zharuk I. (eds) 2006. Directory of Ukraine's Wetlands. Wetlands International Black Sea Programme, Kyiv (in Ukrainian with English summary).

Marynych O. M. \& Shyshchenko P. G. 2005. Fizychna geografiya Ukrayiny: Pidruchnyk. Znannya, Kyiv.

MASJUK N. P. 1958. Protokokovi vodorosti ozer zakhidnoukrajinskogo Polissya. Vydavnytstvo AN URSR, Kyiv.

Matvienko O. M. 1965. Zolotysti vodorosti - Chrysophyta. In: A. M. OKSNER (ed.), Vyznachnyk prisnovodnyh vodorostey Ukrainskoi RSR. 3(1): 1-368. Naukova Dumka, Kyiv.

Moshkova N. O. \& Vodopian N. S. 1975. On flora of the Perga river overgrowths in the Polissia Reserve. Ukrains' $k$. Bot. Zhurn. 32(4): 415-424 (in Ukrainian with English summary).

Oda A. C. R. \& Bicudo C. E. M. 2006. Ecology of Peridinium gatunense and Peridinium umbonatum (Dinophyceae) in a shallow, tropical, oligotrophic reservoir (IAG Pond), Săo Paulo, southeast Brazil. Acta Limnologica Brasiliensia 18(2): 165-180.

Orlov O. O., Iakushenko D. M. \& Borysova O. V. 2009. Syntaksonomiya roslynnosti ozera Bile (Rivnenskyj pryrodnyj zapovidnyk). In: M. D. BuDz et al. (eds), Materials of Scientific Conference dedicated to $10^{\text {th }}$ anniversary of Rivnensky Nature Reserve "Zberezhennya ta vidtvorennya pryrodno-zapovidnyh terytorij” (11-13 June 2009, Sarny, Ukraine), pp. 258-266. Rivnenska Drukarnya, Rivne.

Palamar-Mordvintseva G. M. \& Tsarenko P. M. 2015. Algofloristic zoning of Ukraine. Int. J. Algae 17(4): 303-338.

Palamar-Mordvintseva G. M., Shindanovina I. P. \& Belous E. P. 2009. Species and taxonomic diversity of Desmidiales from Shatsky National Natural Park (Ukrainian Polissya). Algologia 19(1): 83-91 (in Russian with English summary).

Pasztaleniec A. \& Poniewozik M. 2010. Phytoplankton based assessment of the ecological status of four shallow lakes (Eastern Poland) according to Water Framework Directive - a comparison of approaches. Limnologica 40: 251-259.

Prygiel J. \& Coste M. (eds) 2000. Guide Méthodologique pour la mise en oeuvre de l'Indice Biologique Diatomées. Agences de l'Eau, Ministére de l'Aménagement du Territoire et de l'Environnement, Direction de l'Eau \& CEMAGREF, Paris. 
Radzymovsky D. O. \& Polischuk V. V. 1970. Plankton richky Prypiati. Naukova Dumka, Kyiv.

Topachevsky O. V. \& OKsIYUK O. P. 1960. Diatomovi vodorosti - Bacillariophyta (Diatomeae). In: O. V. TOPACHEVsKY (ed.), Vyznachnyk prisnovodnyh vodorostey Ukrainskoi RSR. 11: 1-412. Naukova Dumka, Kyiv.

Tsarenko P. M. 1984. Analysis of the Chlorococeaceae Flora of Ukrainian Polessie Ukrains 'k. Bot. Zhurn. 41(3): 59-64 (in Ukrainian with English summary).

TSARENKo P. M. 2014a. Algolimnologichna komponenta Shatskyh vodno-bolotnyh ugidd'. In: V. V. KonISHCHUK (ed.), Ekologiya vodno-bolotnyh ugidd' $i$ torfovyshch (zbirnyk naukovyh statej), pp. 273-276. NVP “Interservis", Kyiv.

Tsarenko P. M. 2014b. Shatskyj park - algorezervat flory Ukrayiny? In: P. V. YuRCHuK et al. (eds), Materials of International Scientific Conference "National nature parks: past, present and future” (Svityaz, 23-25 April 2014), pp. 338-343. Komprint, Kyiv.

Tsarenko P. M., Wasser S. P. \& Nevo E. (eds) 2006. Algae of Ukraine: diversity, nomenclature, taxonomy, ecology and geography. 1. Cyanoprokaryota, Euglenophyta, Chrysophyta, Xanthophyta, Raphidophyta, Phaeophyta, Dinophyta, Cryptophyta, Glaucocystophyta and Rhodophyta. Gantner Verlag, Ruggell.

Tsarenko P. M., Wasser S. P. \& Nevo E. (eds) 2009. Algae of Ukraine: diversity, nomenclature, taxonomy, ecology and geography. 2. Bacillariophyta. Gantner Verlag, Ruggell.

Tsarenko P. M., Wasser S. P. \& Nevo E. (eds) 2011. Algae of Ukraine: diversity, nomenclature, taxonomy, ecology and geography. 3. Chlorophyta. Gantner Verlag, Ruggell.

Tsarenko P. M., Wasser S. P. \& Nevo E. (eds) 2014. Algae of Ukraine: diversity, nomenclature, taxonomy, ecology and geography. 4. Charophyta. Gantner Verlag, Ruggell.

Vladimirova K. S. \& Litvinova M. O. 1964. Fitoplankton. In: Y. Y. TSEeB (ed.), Kahovske vodoimysche: hydrobiologichny narys, pp. 30-59. Naukova Dumka, Kyiv.

WOLSKI T. 1927. Materialen zur Cladocerenfauna Polessjens. II. Cladoceren der Polnischen Polessjenseen. Arch. Hydrobiol. Rybactwa 2(3-4): 197-310 (in Polish with German summary).

ApPENDix. Taxonomic list of algal flora of the studied lakes. A - lake Bile, B - Lake Somyne, C - Lake Cheremske, D - Lake Redychi; ${ }^{*}$ - new for Ukrainian flora, ${ }^{* *}$ - rare in Ukrainian flora.

\begin{tabular}{|c|c|c|c|c|}
\hline Taxon / Lake & A & $\mathrm{B}$ & $\mathrm{C}$ & $\mathrm{D}$ \\
\hline \multicolumn{5}{|l|}{ CYANOPROKARYOTA } \\
\hline Anabaena sp. & + & & & \\
\hline Aphanocapsa planctonica (G. M. Sm.) Komárek \& Anagn. & + & + & & \\
\hline${ }^{* *}$ Aphanothece endophytica (West \& G. S. West) Komárk.-Legn. \& Cronberg & + & & & \\
\hline A. microscopica Nägeli & + & & & \\
\hline A. minutissima (West) Komárk.-Legn. \& Cronberg & + & & & \\
\hline Chroococcus minimus (Keissler) Lemmerm. & & + & & \\
\hline C. turgidus (Kütz.) Nägeli & + & & + & \\
\hline Coelosphaerium kuetzingianum Nägeli & + & & & \\
\hline Cyanothece aeruginosa (Nägeli) Komárek & & & + & \\
\hline Dolichospermum flos-aquae (Bréb. ex Bornet \& Flahault) Wacklin, Hoffman \& Komárek & + & & & \\
\hline D. spiroides (Klebhan) Wacklin, L. Hoffmann \& Komárek & & & + & \\
\hline Geitlerinema splendidum (Grev. ex Gomont) Anagn. & + & & & \\
\hline Gloeocapsa gelatinosa Kütz. & + & & & \\
\hline${ }^{* *}$ Gloeothece subtilis Skuja & & + & & \\
\hline Gloeotrichia pisum Thuret ex Bornet \& Flahault & + & & & \\
\hline Hapalosiphon pumilus Kirchner ex Bornet \& Flahault & & + & & \\
\hline${ }^{* *}$ cf. Leptolyngbya gloeophila (Borzi) Anagn. \& Komárek & + & & & \\
\hline Merismopedia punctata Meyen & + & + & & \\
\hline Microcystis cf. smithii Komárek \& Anagn. & + & & & \\
\hline Nostoc punctiforme (Kütz.) Hariot & & & + & \\
\hline Oscillatoria tenuis C. Agardh ex Gomont & & & + & + \\
\hline Pseudanabaena catenata Lauterborn & + & & & \\
\hline${ }^{* *}$ Rivularia aquatica (De-Wild.) Geitl. & + & & & \\
\hline Snowella lacustris (Chodat) Komárek \& Hindák & + & & & \\
\hline
\end{tabular}


ApPENDIX. Continued.

Taxon / Lake

Spirulina cf. robusta Welsh

Stenomitos frigidus (F. E. Fritsch) Miscoe \& J. R. Johansen

Synechocystis aquatilis Sauv.

Woronichinia naegeliana (Unger) Elenkin

EUGLENOPHYTA

${ }^{* * *}$ Colacium cyclopicola (Gickl.) Woron. \& T. G. Popova

${ }^{* *}$ Distigma curvatum Pringsh.

Euglena ehrenbergii G. A. Klebs

E. gracilis G. A. Klebs

E. pisciformis G. A. Klebs

E. proxima P. A. Dang.

E. tripteris (Duj.) G. A. Klebs

Phacus pleuronectes (Ehrenb.) Dujard.

P. pyrum (Ehrenb.) F. Stein

Trachelomonas rugulosa F. Stein

T. volvocina Ehrenb. var. volvocina

T. volvocina var. punctata Playfair

CHRYSOPHYTA

${ }^{*}$ Chromulina cf. verrucosa G. A. Klebs

${ }^{* *}$ Dynobrion cylindricum var. palustre Lemmerm.

D. divergens O. E. Imhof

Epipyxis utriculus var. pusilla Averintsev

Lagynion scherffelii Pascher

${ }^{* *}$ Lepochromulina calyx Scherff.

${ }^{* * *}$ Pseudokephyrion poculum W. Conrad

Synura uvella Ehrenb. emend. Korschikov

XANTOPHYTA

${ }^{* * *}$ Bumilleria angustata (Starmach) Matv. \& Dogadina

Ophiocytium capitatum Wolle

O. maius Nägeli

O. parvulum (Perty) A. Braun

EUSTIGMATOPHYTA

Vischeria helvetica (Vischer \& Pascher) Hibberd

BACILLARIOPHYTA

Acanthoceras zachariasii (Brun) Simonsen

Achnanthidium exiguum (Grunow) Czarn.

Amphora ovalis (Kütz.) Kütz.

Aulacoseira granulata (Ehrenb.) Simonsen

Brachysira vitrea (Grunow) R. Ross

Caloneis silicula (Ehrenb.) Cleve

${ }^{* *}$ Cavinula scutelloides (W. Sm.) Lange-Bert.

Cocconeis pediculus Ehrenb.

C. placentula Ehrenb. var. placentula

Craticula buderi (Hust.) Lange-Bert.

Cyclotella meneghiniana Kütz.

C. stelligera Cleve \& Grunow

Cymatopleura solea (Bréb.) W. Sm.

${ }^{* *}$ Cymbella aspera (Ehrenb.) Cleve

C. cymbiformis C. Agardh

\begin{tabular}{c|c|c|c}
\hline A & B & C & D \\
\hline+ & & & \\
\hline & + & & \\
\hline & & + & \\
\hline+ & & & \\
\hline
\end{tabular}

\begin{tabular}{|c|c|c|c}
++ & + & & \\
\hline & & + & + \\
\hline & & + & + \\
\hline & + & + & \\
\hline & & + & + \\
\hline & & + & \\
\hline & + & & \\
\hline & + & & \\
\hline & + & & \\
\hline & + & + & + \\
\hline & + & & \\
\hline
\end{tabular}


ApPENDIX. Continued.

Taxon / Lake

C. lanceolata (C. Agardh) Ehrenb.

${ }^{* *}$ C. subcistula Krammer

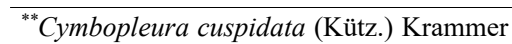

Diploneis ovalis (Hilse) Cleve

Encyonema caespitosum Kütz.

${ }^{* * *}$ E. neogracile Krammer

${ }^{* *}$ E. silesiacum (Bleisch) D. G. Mann

${ }^{* *} E$. vulgare Krammer

Epithemia adnata (Kütz.) Bréb.

E. frickei Krammer

E. sorex Kütz.

E. turgida (Ehrenb.) Kütz.

Eunotia arcus Ehrenb.

E. bilunaris (Ehrenb.) Schaar.

${ }^{* *}$ E. flexuosa (Bréb. \& Kütz.) Kütz.

${ }^{* *} E$. minor (Kütz.) Grunow

${ }^{*}$ E. myrmica Lange-Bert.

${ }^{* *}$ E. naegelii Migula

E. pectinalis (Kütz.) Rabenh.

${ }^{* *}$ E. sylvahercynia Nörpel, Van Sull \& Lange-Bert.

${ }^{*}$ E. tetraodon Ehrenb.

Fragilaria capucina var. vaucheriae (Kütz.) Lange-Bert.

F. crotonensis Kitton

Frustulia disjuncta Lange-Bert.

${ }^{* *} F$. krammeri Lange-Bert. \& Metzeltin

F. vulgaris (Thwaites) De Toni

Gomphonema acuminatum Ehrenb.

G. angustatum (Kütz.) Rabenh.

G. augur Ehrenb.

${ }^{* *}$ G. brebissonii Kütz.

G. capitatum Ehrenb.

G. coronatum Ehrenb.

G. gracile Ehrenb.

G. parvulum Kütz.

G. truncatum Ehrenb.

Halamphora veneta (Kütz.) Levkov

Hantzschia amphioxys (Ehrenb.) Grunow

Lemnicola hungarica (Grunow) Round \& Basson

Navicula cryptotenella Lange-Bert.

$N$. radiosa Kütz.

N. reinhardtii (Grunow) Grunow

$N$. viridula (Kütz.) Ehrenb.

${ }^{* *} N$. vulpina Kütz.

Neidium ampliatum (Ehrenb.) Krammer

N. bisulcatum (Lagerst.) Cleve

N. dubium (Ehrenb.) Cleve

Nitzschia amphibia Grunow

$N$. fonticola (Grunow) Grunow

Pinnularia brebissonii (Kütz.) Rabenh.

\begin{tabular}{|c|c|c|c|}
\hline A & B & $\mathrm{C}$ & $\mathrm{D}$ \\
\hline \multicolumn{4}{|c|}{+} \\
\hline+ & + & & \\
\hline+ & & & + \\
\hline \multicolumn{4}{|l|}{+} \\
\hline \multicolumn{4}{|l|}{+} \\
\hline & & + & \\
\hline \multirow[t]{2}{*}{+} & & & + \\
\hline & + & + & + \\
\hline+ & & + & + \\
\hline \multicolumn{4}{|l|}{+} \\
\hline \multicolumn{4}{|l|}{+} \\
\hline & & & + \\
\hline & & & + \\
\hline & + & + & + \\
\hline \multirow[t]{4}{*}{+} & & + & + \\
\hline & + & + & + \\
\hline & & & + \\
\hline & + & & \\
\hline \multirow[t]{3}{*}{+} & & + & + \\
\hline & & + & + \\
\hline & & & + \\
\hline \multicolumn{4}{|l|}{+} \\
\hline \multirow[t]{4}{*}{+} & + & & \\
\hline & & + & + \\
\hline & & + & + \\
\hline & & + & \\
\hline \multirow[t]{3}{*}{+} & + & + & + \\
\hline & & + & \\
\hline & & & + \\
\hline \multirow[t]{4}{*}{+} & & & \\
\hline & & & + \\
\hline & + & + & + \\
\hline & + & + & + \\
\hline+ & & + & + \\
\hline \multirow[t]{2}{*}{+} & + & + & \\
\hline & & & + \\
\hline \multirow[t]{2}{*}{+} & & & \\
\hline & & & + \\
\hline+ & & + & \\
\hline+ & + & + & + \\
\hline \multicolumn{4}{|l|}{+} \\
\hline \multicolumn{4}{|c|}{+} \\
\hline+ & + & & \\
\hline \multicolumn{4}{|l|}{+} \\
\hline & & & + \\
\hline \multicolumn{4}{|l|}{+} \\
\hline \multirow[t]{3}{*}{+} & & & + \\
\hline & & & + \\
\hline & & + & \\
\hline
\end{tabular}


ApPENDIX. Continued.

Taxon / Lake

${ }^{* * *}$ P. complexa Krammer

${ }^{* *} P$. flexuosa Cleve

${ }^{* *} P$. gracillima Greg.

P. microstauron (Ehrenb.) Cleve

P. nodosa (Ehrenb.) W. Sm. var. nodosa

${ }^{* *}$ P. nodosa var. pseudogracillima A. Mayer

${ }^{* *}$ P. parvulissima Krammer

${ }^{* *}$ P. polyonca (Bréb.) W. Sm. var. polyonka

${ }^{* *}$ P. polyonca var. similis $\mathrm{Krammer}$

${ }^{* *}$ P. rhombarea Krammer

${ }^{* * *}$ P. stidolphii Krammer

${ }^{* *}$ P. subanglica Krammer

P. subcapitata W. Greg

${ }^{* * *}$ P. subrupestris Krammer var. subrupestris

${ }^{* *}$ P. subrupestris var. cruciata Krammer

$P$. viridis (Nitzsch) Ehrenb.

Placoneis placentula (Ehrenb.) Mereschk.

Planothidium frequentissimum (Lange-Bert.) Lange-Bert.

Reimeria sinuata (W. Greg.) Kociolek \& Stoermer

Rhopalodia gibba (Ehrenb.) O. Müll.

Rossithidium linearis (W. Sm.) Round \& Bukht.

Sellaphora pupula (Kütz.) Mereschk.

Stauroneis anceps Ehrenb.

S. gracilis Ehrenb.

Staurosirella pinnata (Ehrenb.) D. M. Williams \& Round

Stephanodiscus hantzschii Grunow

Surirella linearis W. Sm.

Tabellaria fenestrata (Lyngb.) Kütz.

T. flocculosa (Roth) Kütz.

Tabularia fasciculata (C. Agardh) D. M. Williams \& Round

Ulnaria acus (Kütz.) Aboal

U. biceps (Kütz.) Compère

U. ulna (Nitzsch) Compère

DINOPHYTA

Ceratium hirundinella (C. Agardh) Kütz.

${ }^{* *}$ Peridinium gatunense Nygaard

CRYPTOPHYTA

Cryptomonas marssonii Skuja emend. Hoef-Emden \& Melkonian

${ }^{* * *}$ C. obovata Skuja

GLAUCOCYSTOPHYTA

${ }^{* * *}$ Glaucocystis nostochinearum Itzigs.

ChLOROPHYTA

**Acanthococcus aciculiferus Lagerh.

Acutodesmus dimorphus (Turpin) P. Tsarenko

A. pectinatus (Meyen) P. Tsarenko

Ankistrodesmus falcatus (Corda) Ralfs

A. fusiformis Corda ex Korschikov

Aphanochaete repens A. Braun

**Asterococcus limneticus G. M. Sm.

\begin{tabular}{|c|c|c|c|}
\hline A & B & $\mathrm{C}$ & $\mathrm{D}$ \\
\hline & & + & + \\
\hline & & + & + \\
\hline & & + & + \\
\hline & & & + \\
\hline \multirow[t]{12}{*}{+} & & & \\
\hline & & + & + \\
\hline & & + & + \\
\hline & & + & + \\
\hline & & + & + \\
\hline & & + & + \\
\hline & & + & + \\
\hline & & + & + \\
\hline & + & + & + \\
\hline & & + & + \\
\hline & & + & + \\
\hline & + & + & + \\
\hline \multicolumn{4}{|l|}{+} \\
\hline & + & & \\
\hline \multicolumn{4}{|l|}{+} \\
\hline \multirow[t]{2}{*}{+} & & & + \\
\hline & + & + & \\
\hline \multicolumn{4}{|l|}{+} \\
\hline \multirow[t]{2}{*}{+} & & + & \\
\hline & & + & \\
\hline \multicolumn{4}{|l|}{+} \\
\hline+ & + & + & + \\
\hline \multicolumn{4}{|l|}{+} \\
\hline & + & + & + \\
\hline \multirow[t]{2}{*}{+} & + & + & + \\
\hline & + & & \\
\hline+ & + & & \\
\hline+ & + & & \\
\hline+ & & & \\
\hline
\end{tabular}

\begin{tabular}{l|l|l|l|l}
+ & + & & \\
\hline & + & & \\
\hline
\end{tabular}

\begin{tabular}{l|c|c|c|c} 
& & + & & \\
\hline & & & + & \\
\hline & & & + & + \\
\hline & & & + & \\
\hline & + & + & & \\
\hline & & + & \\
\hline+ & & & \\
\hline+ & + & + & \\
\hline+ & + & + & + \\
\hline
\end{tabular}


ApPENDIX. Continued.

\begin{tabular}{|c|c|c|c|c|}
\hline Taxon / Lake & A & $\mathrm{B}$ & $\mathrm{C}$ & $\mathrm{D}$ \\
\hline Bulbochaete sp. ster. & + & + & & \\
\hline Characium cf. acuminatum A. Braun & + & & & \\
\hline Chlamydomonas oblonga E. G. Pringsh. & & + & & \\
\hline Chlorella vulgaris Beij. & & + & & \\
\hline Chlorococcum lobatum (Korschikov) F. E. Fritsch \& John & & + & & \\
\hline Coelastrum microporum Nägeli & + & & & \\
\hline \multicolumn{5}{|l|}{ Crucigeniella irregularis (Wille) P. Tsarenko \& D. M. John } \\
\hline Desmodesmus armatus (Chodat) E. Hegew. & + & + & & \\
\hline${ }^{* *}$ D. magnus (Meyen) P. Tsarenko & + & + & & \\
\hline D. protuberans (F. E. Fritsch \& Rich) E. Hegew. & & & & + \\
\hline Dictyosphaerium sp. & + & & & \\
\hline Echinosphaeridium nordstedtii Lemmerm. & & & + & \\
\hline Elakatothrix genevensis (Reverd.) Hindák & & & + & \\
\hline Eudorina elegans Ehrenb. & & & + & + \\
\hline Kirchneriella lunaris (Kirchn.) Moeb. & & & + & \\
\hline K. obesa (West) Schmidle & & + & & \\
\hline Microspora sp. & & + & & \\
\hline Microthamnion kuetzingianum Nägeli ex Kütz. & & & + & \\
\hline M. strictissimum Rabenh. & & + & + & \\
\hline Monoraphidium arcuatum (Korschikov) Hindák & & + & + & \\
\hline M. contortum (Thur.) Komárk.-Legn. & & + & + & + \\
\hline M. griffithii (Berk.) Komárk.-Legn. & & & + & \\
\hline M. minutum (Nägeli) Komárk.-Legn. & + & & & \\
\hline M. tortile (West \& G. S. West) Komárk.-Legn. & & + & & \\
\hline Mychonastes homosphaera (Skuja) Kalina \& Punčoch. & + & + & & \\
\hline Oedogonium sp. ster. & + & + & + & + \\
\hline Oocystis parva West \& G. S. West & + & & & \\
\hline O. solitaria Wittr. & & & + & + \\
\hline Palmodictyon lobatum Korschikov & & & + & \\
\hline P. varium (Nägeli) Lemmerm. & & & + & \\
\hline${ }^{* *} P$. viride Kütz. & & & + & + \\
\hline Pandorina morum (O. F. Müller) Bory & & & + & + \\
\hline${ }^{* *}$ Parachlorella kessleri (Fott \& Novákova) Krienitz et al. & & + & & \\
\hline Phacotus coccifer Korschikov & & & + & + \\
\hline Pseudocharacium obtusum (A. Braun) Petry-Hesse & & + & & \\
\hline Pseudopediastrum boryanum (Turpin) E. Hegew. & + & & & \\
\hline Quadrigula korschikovii Komárek & + & & + & \\
\hline Scenedesmus ellipticus Corda & + & & & \\
\hline S. obtusus var. apiculatus (West \& G. S.West ) P. Tsarenko & & & & + \\
\hline S. parvus (G. M. Sm.) Bourr. & & + & & \\
\hline Selenastrum bibraianum Reinsch & & & + & + \\
\hline S. gracile Reinsch & & & + & + \\
\hline Sorastrum spinulosum Nägeli & + & & & \\
\hline Stauridium tetras (Ehrenb.) E. Hegew. & + & & & \\
\hline Stigeoclonium sp. & & + & & \\
\hline Tetraëdron minimum (A. Braun) Hansg. & + & + & & \\
\hline T. regulare Kütz. & & & + & \\
\hline \multicolumn{5}{|l|}{ CHAROPHYTA } \\
\hline Actinotaenium cucurbita (Bréb.) Teil. ex Růžička \& Pouzar & & & + & \\
\hline
\end{tabular}


ApPENDIX. Continued.

Taxon / Lake

${ }^{* *} A$. turgidum (Bréb. ex Ralfs) Teiling ex Růžička \& Pouzar

${ }^{* *}$ A. wollei (West \& G .S. West) Teiling ex Růžička \& Pouzar

Closterium acutum Bréb.

C. dianae Ehrenb. ex Ralfs

${ }^{* *} C$. dianae var. minus Hieron.

C. gracile Bréb. ex Ralfs

C. incurvum Bréb.

C. juncidum Ralfs

C. kuetzingii Bréb.

C. lineatum Ehrenb.

C. moniliferum Ehrenb. ex Ralfs

${ }^{* * *}$ C. praelongum Bréb.

${ }^{* *}$ C. regulare Bréb.

C. setaceum Ehrenb. ex Ralfs

C. striolatum Ehrenb. ex Ralfs

C. venus Kütz. ex Ralfs

Coleochaete scutata Bréb.

${ }^{* *}$ Cosmarium arctoum Nordst.

C. debaryi Arch.

C. depressum (Nägeli) P. Lundell

${ }^{* *} C$. difficile Lütkem.

${ }^{* *}$ C. elegantissimum P. Lundell

C. humile (Gay) Nordst.

C. margaritatum (P. Lundell) Roy \& Bisset

C. meneghinii Bréb.

C. moniliforme Ralfs

C. pachydermum P. Lundell

C. portianum W. Archer

C. pseudopyramidatum P. Lundell

C. punctulatum (Bréb. ex Ralfs) Pal.-Mordv.

C. pygmaeum W. Archer

C. pyramidatum Bréb.

C. subcostatum Nordst.

C. subprotumidum var. gregorii Roy \& Biss.

Cosmoastrum muticum (Bréb. ex Ralfs) Pal.-Mordv. ex Petlov.

C. punctulatum (Bréb. ex Ralfs) Pal.-Mordv.

${ }^{* * *}$ C. retusum var. boreale (West \& G. S. West) Pal.-Mordv.

C. teliferum (Ralfs) Pal.-Mordv.

Cylindrocystis brebissonii (Menegh. ex Ralfs) De Bary

C. crassa De Bary

Euastrum ansatum Ralfs

E. denticulatum (Kirchn.) Gay

Haplotaenium minutum (Ralfs) Bando

Klebsormidium nitens (Menegh.) Lokhorst

Netrium digitus (Ehrenb. ex Ralfs) Itzigs. \& Rothe

*** Octacantium bifidum (Bréb.) Compère

Penium cylindrus Bréb. ex Ralfs

${ }^{* *}$ Spondylosium planum (Wolle) West \& G. S. West

${ }^{* * *}$ Staurastrum aculeatum [Ehrenb.] Menegh. ex Ralfs

\begin{tabular}{|c|c|c|c|}
\hline A & B & $\mathrm{C}$ & $\mathrm{D}$ \\
\hline \multicolumn{4}{|l|}{+} \\
\hline & & + & \\
\hline & & + & \\
\hline & & + & \\
\hline & & + & \\
\hline & & + & \\
\hline & & + & \\
\hline & & + & \\
\hline & & + & \\
\hline & & + & \\
\hline \multicolumn{4}{|l|}{+} \\
\hline & & + & \\
\hline & & + & \\
\hline & + & & \\
\hline & & + & \\
\hline & & + & \\
\hline & & + & + \\
\hline & & + & \\
\hline & & + & \\
\hline & & + & \\
\hline & & + & \\
\hline & & + & \\
\hline & & + & + \\
\hline \multicolumn{4}{|l|}{+} \\
\hline \multicolumn{4}{|l|}{+} \\
\hline \multicolumn{4}{|l|}{+} \\
\hline & & + & \\
\hline & & + & \\
\hline & & + & + \\
\hline & & + & \\
\hline \multirow[t]{11}{*}{$?$} & & + & \\
\hline & & + & + \\
\hline & & + & + \\
\hline & & + & \\
\hline & & + & \\
\hline & & + & \\
\hline & & + & \\
\hline & & + & \\
\hline & & + & \\
\hline & & + & \\
\hline & & + & \\
\hline \multirow[t]{2}{*}{+} & & + & \\
\hline & & + & \\
\hline \multicolumn{4}{|l|}{+} \\
\hline & + & + & \\
\hline & & + & \\
\hline & & + & \\
\hline \multirow[t]{2}{*}{+} & & & \\
\hline & & + & \\
\hline
\end{tabular}


ApPEndix. Continued.

\begin{tabular}{|c|c|c|c|c|}
\hline Taxon / Lake & A & $\mathrm{B}$ & $\mathrm{C}$ & $\mathrm{D}$ \\
\hline${ }^{* *}$ S. boreale West \& G. S. West & & & + & + \\
\hline S. cyrtocerum Bréb. ex Ralfs & & & + & \\
\hline S. furcatum var. aciculiferum (West) Coesel & & & + & \\
\hline${ }^{* *}$ S. furcatum var. spinosum (Wittr. \& Nordst.) Petlov. & & & + & \\
\hline S. gracile Ralfs ex Ralfs & + & & & \\
\hline${ }^{* *} S$. gracile var. nanum Wille & & & + & \\
\hline S. margaritaceum (Ehrenb.) ex Ralfs & & & + & + \\
\hline S. cf. oxyacanthum W. Archer & + & & & \\
\hline S. polymorphum Bréb. ex Ralfs emend. Nordst. ex Grönblad & & & + & + \\
\hline${ }^{* *}$ Staurodesmus corniculatus (P. Lundell) Teiling & + & & & \\
\hline S. incus (Bréb. ex Ralfs) Teiling & & & + & \\
\hline${ }^{* *}$ S. pterosporus (P. Lundell) Bourr. & & & + & \\
\hline Tetmemorus brebissonii (Menegh.) ex Ralfs & & & + & \\
\hline T. laevis (Kütz.) ex Ralfs & & & + & \\
\hline${ }^{* *}$ T. laevis var. minutus (De Bary) Willi Krieg. & & & + & \\
\hline${ }^{* *}$ Tortitaenia obscura (Ralfs) Brook & & & + & \\
\hline T. trabeculata (A. Braun) Brook & & & + & \\
\hline Xanthidium antilopaeum (Bréb.) ex Kütz. & & & + & \\
\hline$X$ cristatum Bréb. ex Ralfs & & & + & \\
\hline
\end{tabular}

